Tomasz Nowicki

Uniwersytet Gdański

\title{
Zoo jako projekt socjalizacyjny
}

Tematem niniejszego artykułu jest dekonstrukcja zoo. W związku z tym spróbuję wyodrębnić dwie warstwy tekstu, jakim jest zoo, i przedstawić wnioski z dokonanych analiz. Pytaniami roboczymi, które stawiam, są: w jaki sposób zoo konstruuje pojęcie natury, gatunku i zwierzęcia? oraz w jaki sposób zoo wpisuje się w wytworzony w zachodniej kulturze model wiedzy?

Nowożytna forma ogrodów zoologicznych o charakterze edukacyjnym i rozrywkowym pojawiła się w XVIII wieku. Definicyjnie przyjmuje się, że ogrodami zoologicznymi są: „parki publiczne, w których wystawia się na pokaz zwierzęta, przede wszystkim dla celów rekreacyjnych lub edukacyjnych" (Jamieson 2011: 192). Pierwszym otwartym i istniejącym do dziś ogrodem zoologicznym jest wiedeńskie zoo, ufundowane w 1752 roku. Wraz z rozwojem nauk przyrodniczych i formułowanych teorii ewolucyjnych wzrosło zainteresowanie zwierzętami; mający wpisany w swój statut rozrywkę i edukację ogród zoologiczny powstał w Paryżu w 1793 roku. Mimo wysokiej śmiertelności zwierząt przenoszonych z ich naturalnego środowiska do Europy przedsięwzięcie zakładania przez największe miasta ogrodów zoologicznych spotkało się z dużym entuzjazmem włodarzy. Zanim otworzono kolejne londyńskie zoo (1828) do zwierząt trzymanych w ogrodach dołączyli ludzie dostarczani z europejskich kolonii, wśród których najwięcej było Afrykanów, chociaż dużym zainteresowaniem cieszyły się także ekspozycje osób niepełnosprawnych lub dotkniętych chorobami genetycznymi. Takie wystawy nazywano ludzkimi zoo czy też etnologiczną ekspozycją lub Wioskami Murzynów. Kolejne ogrody zoologicznie powstawały w: Amsterdamie (1838), Berlinie (1843), Melbourne (1857), Moskwie (1864), Filadelfii (1874), Buenos Aires (1888) i Kairze (1890). W późniejszym okresie do wymienionych funkcji zoo dołączyły zadania ochrony zagrożonych wyginięciem gatunków zwierząt oraz cele badawcze. 


\section{Zoo jako rozrywka}

Pierwszą funkcję zoo, jaką jest rozrywka, charakteryzuje voyeuryzm spojrzenia. Czynnikiem powodującym dostarczenie przyjemnych wrażeń w zoo jest zmysłowa potrzeba kontaktu z przyrodą. Na trajektorii widz - patrzenie - obiekt dochodzi do ucieleśnienia oraz przestrzennego osadzenia odczuć i emocji związanych z wystawieniem zwierząt. Dystans, przyswojenie, obiektywizacja - czyli uprzedmiotowienie - jako elementy spojrzenia voyeurysty podkreślają władzę wiktymizującą zwierzęta sprowadzone do obiektu.

Wnioski na temat dominacji zasady przyjemności potwierdzają badania przeprowadzone w ogrodzie w Buffalo (New York), które pokazały bardzo niską skuteczność edukacyjną tej placówki. Z badań tych wynikało, że osoby odwiedzające ogrody zoologiczne nie są zainteresowane czynnikiem edukacyjnym, lecz ich głównym motywem zwiedzania jest dostarczenie wrażeń w postaci rozrywki (Jamieson 2011: 197). Badania frekwencji i populacji odwiedzających ogrody zoologiczne wskazują na fakt, że z zoo pod względem liczby zwiedzających nie mogą konkurować muzea czy też galerie.

John Urry i Phil Macnaghten zwracają uwagę na to że, aby przyroda stała się dla człowieka atrakcyjna, trzeba nią zawładnąć, co z kolei każe zwrócić uwagę na władczość patrzenia (Macnaghten, Urry 2005: 156). To zawłaszczanie oznacza poddanie doświadczenia zmysłowego hegemoni wizualności, która przeobrażała przyrodę w swego rodzaju spektakl. Camille Paglia ujęła to w następujący sposób: „W przyrodzie, muszę stwierdzić, nie ma nic pięknego. Przyroda jest pierwotną siłą, prymitywną i chaotyczną. Piękno jest naszą bronią przeciw przyrodzie... Piękno zatrzymuje i zamraża kipiący strumień przyrody" (Macnaghten, Urry 2005, za: Paglia 1990). Ujarzmione w ten sposób zwierzęta stają się ucieleśnieniem zwycięstwa męskiego spojrzenia, których reprezentacja staje się potwierdzeniem optycznej prawdy. Identyfikacja patrzącego z obrazem artefaktu zwierzęcia staje się zatem możliwa poprzez obramowanie tego doświadczenia w przyjemność czerpaną z utożsamienia ze wzrokiem (władzą spojrzenia) i obserwacji podporządkowania. Jacques Derrida, nawiązując do Jacques’a Lacana, nazywa to doświadczenie narcyzmem, upodmiotowienie człowieka zachodzi $\mathrm{w}$ przeglądaniu się w zwierciadle własnej konstrukcji przyrody. Zwierzęta w warunkach wiwaryjnych egzemplifikują niewolę jako oddanie, stereotypię ${ }^{1}$ jako infantylizację. Zwierzęta

${ }^{1}$ „Stereotypie ruchowe (zool.) - powtarzające się identyczne lub prawie identyczne zespoły ruchów zwierząt; mogą stanowić naturalny składnik ceremonii behawioralnych zwierząt, zwłaszcza tańców, najczęściej jednak są wyrazem przejściowego zaburzenia lub trwałej aberracji psychicznej, a u ludzi - nawet choroby psychicznej; zaburzenia pojawiają się jako zjawiska reaktywne w warunkach deprywacji, np. wskutek trzymania w izolacji zwierząt społecznych odbywających sezonowe wędrówki, braku miejsca w klatce czy boksie, złej hodowli lub wskutek unieruchomienia zwierzęcia; najczęściej występujące stereotypie ruchowe to: kręcenie lub kiwanie głową, obroty lub zwroty całego ciała, bieganie tam i z powrotem po stałej trasie, zwykle przy ogrodzeniu, kiwanie się (np. kiwanie się na boki na przednich nogach 
powracają w konsumpcji przyrody jako przeciwieństwo zdziczenia i chaosu, jaki kojarzymy z dziewiczą przyrodą. Tabliczki umieszczone przy klatkach i wybiegach udzielają im języka, który ukazuje zwierzę w jego jednostkowości i złożoności jako gatunek. Estetyzacja sceny, w jakiej widzimy zwierzę w zoo, pozwala dostrzec jego zubożoną naturę jako piękno. Proces kulturowego zniekształcania Theodor Adorno i Max Horkheimer ujęli w następujący sposób: „Zza męskiego podziwu dla piękności wyziera jednak wciąż gromki śmiech, bezmierne szyderstwo, barbarzyński żart siłacza wobec impotenta: w ten sposób siłacz zagłusza tajemny strach przed impotencją, śmiercią, regresem w naturę" (Horkheimer, Adorno 2010: 244). Przypomina to o obsceniczności oburzenia, jakie przeszło przez media w związku z zabójstwami w kopenhaskim zoo, które zakłóciły kultywowanie piękna, czyniąc widzialną prawdę o tym, co robimy ze zwierzętami w przemyśle spożywczym i rozrywkowym. A przecież doszło tylko do uczynienia widzialnym tego, co Paul McCartney wyraził w słowach „Gdyby rzeźnie miały szklane ściany, każdy byłby wegetarianinem” (McCartney 2010). Władze kopenhaskiego ogrodu zoologicznego wyjaśniały, że morderstwo żyrafy i lwów przecież niczym nie różniło się od selekcji naturalnej, miało egzemplifikować naturę dziką i bezwzględną, inną niż oswojona natura w zoo. Kopenhaski błąd polegał na zapomnieniu o tym, że wszelkie odstępstwa od sielankowej wizji przyrody są karane jako zbrodnie przeciwko ideologii szowinizmu gatunkowego.

Organizacja tego, co widzialne w zoo, dzieli się na estetyzację zwierząt oraz poznawczą warstwę przygotowanej sceny. Estetyzacja i wartość poznawcza składają się na zasadę przyjemności i dyscyplinowania spojrzenia. Dyscyplinowanie odbywa się przez wprowadzenie reguł przestrzennego porządku zwiedzania, mapy zoo - czyli przestrzennej symbolicznej wizualizacji z lotu ptaka (abstrakcji spojrzenia), kamer, nadzoru obsługi oraz regulaminu. Mapy zoo dyscyplinują podróż spojrzenia oraz porządkują podział przestrzenny na miejsce usytuowania spojrzenia jako trasy zwiedzania, czyli miejsca kultury oraz miejsca usytuowania zwierząt jako przyrody. Wzrok staje się wszechobecnym spojrzeniem podążającym za sobą. Jak w panoptykonie spojrzenie zostaje podwójnie zorganizowane - jako spojrzenie zwiedzającego oraz jako wszechogarniająca siła spojrzenia porządkującego podziały: kultura - natura, ludzkie - nieludzkie.

Ponadto władza spojrzenia zostaje wzmocniona przez rolę technologii w kulturze wizualnej i uprzemysłowieniu zmysłu wzroku. Kamery i aparaty pozwalają na widzenie pojedyncze, neutralne, izolowane i odcieleśnione. Tworzony w ten sposób

przez konie trzymane w ciasnych boksach, tzw. konie tkające) lub kiwanie i kulenie się z głową ukrytą w dłoniach przez makaki hodowane w izolacji. Stereotypie ruchowe wywołane przebywaniem w skąpym otoczeniu występują w wyniku braku zmian bodźców sterujących, powodując „zamrożenie” składowej orientującej ruchu; stereotypie te mogą ustąpić po uwolnieniu zwierzęcia, inne, np. wynikłe z choroby sierocej, zazwyczaj pozostawiają trwałe uszkodzenia psychiczne i behawioralne"; https://encyklopedia.pwn.pl/haslo/stereotypie-ruchowe;3979622. html [dostęp: 7.11.2017]. 
dystans pozwala na zamrożenie obserwowanych zwierząt oraz na potwierdzenie oddzielenia obserwatora od tego, co obserwowane. Urry i Macnaghten zwracają uwagę na to, że doświadczanie przyrody coraz częściej staje się hiperrealne i hiperzmysłowe, przypominając tym samym symulację (Macnaghten, Urry 2005: 167). Kamery i techniki wizualizacji online pozwalają na zwiedzenie zoo bez wychodzenia z domu. Ogrody coraz częściej przypominają parki rozrywki. W architekturę dostępną dla turysty zostaje wpisana możliwość wypoczynku poprzez rozmieszczanie na terenie ogrodów ławek, sklepów z napojami i jedzeniem, barów oraz sklepów z upominkami i pamiątkami. Donna Haraway pojawienie się nowych technologii wzmacniających doświadczenie wzrokowe opisuje jako „[...] technologiczny festyn (który) szybko zmienia widzenie w niepohamowane obżarstwo; wszystko wskazuje na to, że nieskończenie ruchoma wizja zmieni mityczną boską zdolność widzenia wszystkiego znikąd w zwykłą życiową praktykę" (Haraway 2008: 10).

Ten okocentryczny nadmiar spłyca zwierzęcą cielesność do powierzchni. Zawładnięta zwierzęcością relacja do ciała w zachodniej kulturze przybiera postać sfeminizowanej natury. Feministyczne krytyki koncepcji natury podkreślają znaczenie epoki kolonialnej, kiedy to eksplozja podboju Afryki, Azji i Ameryki doprowadziła do rozwoju niewolnictwa, rasizmu, militaryzmu, kapitalizmu i trzymania egzotycznych zwierząt w niewoli. Anne McClintock takie zawłaszczenie opisuje jako erotykę gwałtu, w której biały mężczyzna podbijał przyrodę i konstruował podbite ciała w kategoriach radykalnej inności (McClintock 1995).

\section{Zoo jako poznanie}

Drugą funkcją ogrodów zoologicznych jest poznanie. Tę rolę w dyskursach zoo nazywa się przede wszystkim edukacją, niemniej to, co moim zdaniem jest istotne $\mathrm{w}$ tej perspektywie, to reprodukowanie charakterystycznego dla projektu oświecenia doświadczenia zmysłowej obserwacji. W tym sensie twierdzę, że wycieczka do zoo to historyczna podróż do źródła paradygmatu poznania i pytanie o sposób i znaczenie, jakie nadawane jest reprezentacji zwierząt. Podobnie jak panoptykon tradycja istnienia ogrodów zoologicznych i ukształtowanego wokół nich dyskursu naucza, że wytwarzanie obiektywności, czyli normatywności, to proces konstruowania warunków ludzkiego spojrzenia jako relacji wiedzy-władzy. Michel Foucault w Słowach i rzeczach rekonstruuje dzieje rozwoju historii naturalnej jako procesu mającego prowadzić do produkcji tablic wprowadzających ład w reprezentację badanych obiektów (Foucault 2006: 119-151). Proces ten znajduje swoje ucieleśnienie $\mathrm{w}$ zoo $\mathrm{w}$ postaci stawiania tablic informacyjnych klasyfikujących poszczególne gatunki zwierząt. Materiałem badawczym przestają być jedynie biblioteki i archiwa, w których przechowywana jest wiedza zakodowana $\mathrm{w}$ formie druku. Źródłem wiedzy stają się przestrzenie, w których zestawia się rzeczy: zielniki, kolekcje, ogrody. Ślad po tej metodzie pozostaje do dziś w dyskursie zoo, 
w którym zwierzęta określane są mianem kolekcji². Taka organizacja wystawionej na spojrzenie rzeczy pojawia się w przestrzeni znaków gotowych na wchłonięcie zwierzęcia przez dyskurs. Foucault ujmuje to w następujący sposób:

Powiada się często, że na tworzenie ogrodów botanicznych i kolekcji zoologicznych przekłada się nowa ciekawość do roślin i zwierząt egzotycznych. W istocie wzbudzały one zainteresowanie od bardzo dawna. Zmieniło się jedno - przestrzeń, gdzie można je ujrzeć i w której można je opisywać. W Renesansie osobliwość zwierzęcia powoływała spektakl: wchodziła w skład festynów, pojedynków, realnych albo fikcyjnych bojów, odgrywania legend, podczas których bestiarium odsłaniało odwieczne fabuły. Gabinet historii naturalnej i ogród urządzone w epoce klasycznej zastępują powracający bieg „pokazów” wyłożeniem rzeczy „na stół”. Między widowiska a katalog nie wślizgnęła się żądza wiedzy, lecz nowy sposób wiązania rzeczy ze spojrzeniem i dyskursem. Nowy sposób tworzenia historii (Foucault 2006: 124).

Obserwacja skupia się na rejestracji tego, co oczywiste i przestrzenne. Dochodzi tym samym do wykluczenia niepewności poprzez skrócenie dystansu między słowem a rzeczą. Ta postawa zostaje wzmocniona poprzez uprzywilejowanie ludzkiego ciała jako instrumentu obiektywizującej widzialności poprzez posiadanie wzroku i języka. Wytworzone w ten sposób podłoże epistemologiczne pozwala na metodyczną i systemową klasyfikację przyrody. Zwierzę zostaje sklasyfikowane jako gatunek $\mathrm{w}$ grze różnicujących cech, jego istnienie zostaje potwierdzone na powierzchni tego, od czego się odróżnia. Jednak, aby historia naturalna mogła zaistnieć i rozwinąć się w oświeceniu, konieczne jest rozszerzenie spojrzenia poza kontynent europejski. Kolejnym krokiem jest zawładnięcie tym, co ujrzał wzrok kolonizatora, i sprowadzenie tego do Europy w celu nadania tym rzeczom nazwy i ładu. Twórca taksonomii Karol Linneusz wyrażał zdziwienie wobec faktu, że natura nie odzwierciedla porządku rozumu i umieszcza w tych samych miejscach organizmy, których nie łączą wspólne cechy. Konieczne zatem jest wprowadzenie do obserwacji warunków pozwalających na transfigurację nieuporządkowanej natury i wskazanie jej miejsca w porządku laboratorium, ogrodu botanicznego i zoologicznego. Podział na przyrodę i społeczeństwo w tej organizacji porządku poznania staje się coraz bardziej sztuczny i przestrzenny. Linneusz wyraził to w następujący sposób:

Metoda dusza nauki, desygnuje przy pierwszym podejściu jakiekolwiek ciało naturalne w taki sposób, że ciało to wypowiada właściwą mu nazwę, owa nazwa zaś przypomina wszystkie wiadomości, jakie nagromadziły się z biegiem czasu na temat tak nazywanego ciała - tak oto w najwyższym pomieszaniu odkrywa się suwerenny ład natury (Linneusz 1776: 13, za Foucault 2006: 149)

\footnotetext{
${ }^{2}$ Np. https://www.zoo.gda.pl/history [dostęp: 7.11.2017].
} 
Przyporządkowanie nazw dla poszczególnych istot żywych tworzone jest na jednolitej dwuwymiarowej powierzchni tabeli taksometrycznej. Znajdujące się na powierzchni cechy jednostki wskazują właściwe rubryki taksonomii: rodzaj i gatunek. Niemniej wraz z rozwojem anatomii porównawczej Georges’a Cuviera to budowa wewnętrzna staje się głównym pojęciem kategoryzacji natury. Pojęcie życia zostaje wydobyte $\mathrm{z}$ dotychczas abstrakcyjnej idei natury. Natura podlega wykrajaniu w laboratorium za pomocą skalpela i mikroskopu, tak oto wewnętrzny porządek organizmu czyni się widzialnym. Jednak powierzchnia ciała nie przestaje się liczyć, lecz jej ważność dla porządku indeksowania zostaje złączona $\mathrm{z}$ wewnętrzną funkcją organów. Powstałe w ten sposób klasyfikacyjne napięcie między zewnętrzem i wnętrzem organizmu prowadzi do wyodrębnienia się porządku wegetatywnego roślin i animalnego zwierząt. Zapleczem dostarczającym materiału do sekcji zwłok i rozwoju wiedzy staje się wysoka śmiertelność zwierząt w ogrodach zoologicznych na przełomie XVIII i XIX wieku. Dużą popularnością cieszy się $\mathrm{w}$ tamtym czasie przeprowadzanie publicznych sekcji zwłok zwierząt, takich jak: wielbłądy, nosorożce, renifery itp. Efektem tych badań jest powstanie pierwszego atlasu anatomicznego (Gucwiński, Strojny 1977: 41). Wkład ogrodów zoologicznych w tworzeniu „bazy do nauki” dokumentuje się od 1866 roku. W laboratoriach dochodzi do referencji istot żywych w rzeczy i słowa. Gdy ta praca zostaje wykonana, przyroda staje się widzialna i zrozumiała, można zatem wystawić na spojrzenie tablice taksonomiczne oraz rozmieścić zwierzęta i rośliny w ogrodach według porządku ich indeksowania. Ogrody zoologiczne i botaniczne stają się zatem sceną manifestującą widzialny ład i porządek natury. Władza spojrzenia nie ma wzbudzać jak kiedyś strachu i fascynacji poprzez krwawy spektakl kaźni, ale wprawiać w podziw i osłupienie.

Zoo posiada własną infrastrukturę i organizację, która wprowadza określony porządek spojrzenia. Wysprzątane klatki, kraty, a później także kamery oraz geometrycznie ustalone przestrzenie, po których porusza się wzrok, stają się określonymi wymogami materialno-formalnymi poznania. Jednocześnie mury i płoty oddzielają i wyznaczają przestrzeń zoo, tworząc działający układ zamknięty. Analogicznie do powyższego przebiega przygotowanie obiektów do badania w laboratorium, które odbywa się w następującej sekwencji: redukcja złożoności - pokawałkowanie - izolowanie obiektów - zrozumienie - indeksowanie i katalogowanie ich działania - manipulacja. W przypadku zoo proces laboratoryzacji odbywa się kolejno poprzez sprowadzenie zwierzęcia $\mathrm{z}$ naturalnego złożonego środowiska i umieszczenie w kontrolowanej przestrzeni klatki bądź wybiegu oraz oddzielenia od innych gatunków; następnie przeprowadza się proces izolacji obiektu i wyodrębnienia jego cech mogących zaistnieć w przygotowanych warunkach, które umożliwią jego hodowlę i reprodukcję; kolejnym krokiem jest przygotowanie tablicy przedstawiającej dystynktywne cechy wyizolowanego obiektu; na koniec następują badania mające na celu manipulację gatunkami i ich zrozumienie. Aby jednak system zoo mógł stanowić sprawnie działający układ, musi uporać się z problemem 
wysokiej śmiertelności zwierząt i zrozumieć sposoby ich reprodukcji w warunkach wiwaryjnych. Jednak na początkowym etapie rozwoju wiedzy na temat zwierząt działanie ogrodów ogranicza się do reprodukcji samej idei zoo. Aby zoo stało się działającym układem zamkniętym, należy zmierzyć się z wysoką śmiertelnością zwierząt, która początkowo daje pretekst do dostarczania dużej ilości cennych eksponatów dla muzeów zoologicznych i laboratoriów. Uzyskane w ten sposób materiały służą do badań anatomiczno-morfologicznych. Pierwsze próby ekstrapolacji zdobytej w ogrodach wiedzy na terenach pierwotnych środowisk życia zwierząt zazwyczaj kończyły się porażką (Gucwiński, Strojny 1977: 41). Dlatego też największej wagi zadaniem dla nowo powstających ogrodów było zrozumienie biologii rozrodu zwierząt. Od poznania warunków rozrodu, okresu godowego oraz sposobu karmienia wielu gatunków zależała kontynuacja systemu zoo i reprodukcja zwierząt w niewoli. Wiedziano też, że uzyskane w ogrodach wyniki badań są jedynymi, jakie udaje się technicznie przeprowadzić i nie ma możliwości porównania ich z wynikami badań terenowych. Problem braku porównania badań wiwaryjnych z terenowymi pozostał nierozwiązany do dziś. Z badań dokonanych w 1995 roku przez Ben Beck, zastępcę dyrektora National Zoological Park w Waszyngtonie, wynika, że na 145 zarejestrowanych restytucji zwierząt, w których uczestniczyło 115 gatunków, 16 zakończyło się pomyślnie, z czego połowa z nich należała do kategorii zwierząt zagrożonych. Przyczyną porażki w aplikacji posiadanej wiedzy było to, że naturalne środowiska zwierząt, które przyszły na świat w zoo, zanikły bądź uległy degradacji, ponadto ignorowano sam proces zmian biologicznych, jaki zachodził w organizmach zwierząt wyhodowanych w niewoli (Jamieson 2011: 203). Innymi słowy pomijano fakt, że wiedza zdobyta w warunkach wiwaryjnych będzie skutecznie działała tylko w podobnych warunkach.

Wysunięcie na pierwszy plan zagadnienia reprodukcji i hodowli zwierząt każe nam znowu powrócić do problemu statusu spojrzenia na zwierzęta tym razem od strony lingwistycznej. Kategorie gatunek i zwierzę narzucają traktowanie indywiduów jako wielości, co wyrażane jest w posługiwaniu się trzecią osobą liczby mnogiej (one/oni), niepostrzeganie ich jako podmiotów (ja), czyli w pierwszej osobie liczby pojedynczej, czy też jako partnerów w dialogu (ty), czyli w drugiej osobie liczby pojedynczej. Na użycie tej formy fleksyjnej w odniesieniu do zwierząt i gatunków zwrócił uwagę Derrida, ujmując to w następujący sposób:

Chciałbym usłyszeć liczbę mnogą zwierzęta w liczbie pojedynczej. Nie ma żadnego Zwierzęcia w ogólnej jednostkowości, oddzielonego od człowieka jedną, niepodzielną granicą. Powinniśmy sobie wyobrazić istnienie „żywych stworzeń”, których wielość nie może zostać złożona w jedną figurę zwierzęcości, którą można by po prostu przeciwstawić ludzkości (Derrida 2008).

Wmieszanie każdego nieludzkiego indywiduum w kategorię ogólną zwierzę bądź gatunek, jak zauważył Derrida, nie było błędem przeciwko rygorowi myślenia, lecz dyskursywną strategią szowinizmu gatunkowego, grzechem przeciwko 
empiryzmowi. To właśnie ten zabieg fleksyjnej multiplikacji tego, co jednostkowe, zapewnił trwałość szowinizmowi gatunkowemu. Richard D. Ryder używa terminu szowinizmu gatunkowego $\mathrm{w}$ celu nazwania błędu w naszym moralnym rozumowaniu. W podobnym duchu czytamy o tym u Richarda Dawkinsa, który wyjaśnia szowinizm gatunkowy jako błędny nawyk nieciągłości naszego umysłu, który dąży do rozumienia pojęcia "gatunku” na przestrzeni ścisłych, nieprzekraczalnych granic moralności. Przy pomocy terminu umysłu nieciągłego Dawkins nazywa dążenie do wytyczania granic tam, gdzie ich nie ma, i poszukiwanie ścisłości semantycznej dla kategorii, które definiuje się w oparciu o zachodzące między nimi związki i relacje. Problem ten ma długą tradycję sięgającą starożytności, która od średniowiecza aż do dziś nosi nazwę sporu między statusem uniwersaliów i nominaliów. Innymi słowy, wszelka forma wykluczenia tworzy się jako napięcie między uznaniem pierwszeństwa w definiowaniu jakiejś kategorii istot jako zbioru ogólnego kosztem uznania przejawów ich jednostkowego istnienia jako manifestacji zbioru cech pojęcia ogólnego. W odniesieniu do zoo możemy zauważyć, że ujęcie roli i funkcji zoo jako hodowli, kolekcji i reprodukcji jest konsekwencją ujęcia zwierząt w kategorii gatunku. Dlatego w dyskursie zoo pierwszeństwo zyskuje naukowo-technologiczna kwestia zastępowalności, reprodukcji i bioróżnorodności gatunków poprzez chów wsobny mający za zadanie selekcję materiału genetycznego zwierząt. W przekazach uzasadniających rasowanie (gatunkowanie) nawet reprodukcja zwierząt występujących obecnie na wolności zaliczana jest do działań ekologicznych, ponieważ wiedza i doświadczenie zdobywane w ten sposób mają uchronić w przyszłości żyjące jeszcze na wolności zwierzęta przed zagładą (Gucwiński, Strojny 1977: 45-52). Traktowanie zwierząt w kategorii gatunku ma także podstawę $\mathrm{w}$ mechanicystycznym podejściu do zwierzęcego organizmu - koncepcji zapoczątkowanej przez Kartezjusza, który twierdził, że zwierzę to mechanizm, dający się wytworzyć i zastąpić innym. To uzasadnia twierdzenie, że niektóre zwierzęta, takie jak: żubr, jeleń milu, gnu brunatne, okapi czy koń Przewalskiego, żyją jedynie dlatego, że istnieją ogrody zoologiczne. Powiada się, że gdyby nie istnienie zoo, gatunki te wyginęłyby. Tak więc powodem hodowli i zabijania zwierząt jest osiągnięcie korzyści gatunkowej, jaką odniosą zwierzęta pojawiające się w miejsce ich zabitych poprzedników, oraz korzyść, jaką odniosą nasi potomkowie z możliwości zaspokojenia swoich potrzeb estetycznych - głodu spojrzenia. Koncepcja „korzyści” czy też „interesu” w byciu przetrzymywanym w niewoli przeniknęła do dyskursu zoo w postaci darwinizmu przyjmującego za jednostkę doboru naturalnego gatunek. Dlatego w ramach sukcesów wiwaryjnych ogrodów zoologicznych jako uzasadnienie ochrony bioróżnorodności gatunków prowadzi się chów wsobny i dokonuje się selekcji materiału genetycznego zwierząt, poddając osobniki o zbyt spokrewnionych pulach genetycznych recyklingowi. W ramach tych praktyk nadwyżkowe zwierzęta sprzedawane są różnym instytucjom lub do odstrzału na prywatnych obszarach łowieckich. Stosuje się także zabijanie nadwyżkowych zwierząt na terenie zoo, by podać je potem do spożycia innym zwierzętom (Jamieson 2011: 202). W ogrodach zoologicznych prowadzi 
się także eksperymenty $\mathrm{z}$ międzygatunkowym krzyżowaniem zwierząt. Wiele istniejących obecnie krzyżówek zwierząt powstało w ogrodach zoologicznych, szacuję się tę liczbę na około 70\% nowych modyfikacji genetycznych (Gucwiński, Strojny 1977: 44). Koncepcja zastępowalności życia przypisuje wartość istnieniu gatunków, a nie poszczególnym przedstawicielom tychże gatunków. Jednak gatunek jako forma trwania zwierząt nie posiada wsobnej wartości życia, która przysługuje jedynie indywiduom. Zwierzęta bowiem nie mają i nie mogą mieć interesów związanych z trwaniem ich gatunków z powodu nieposiadania odpowiedniej struktury mentalnej pozwalającej im na tego typu abstrahowanie. Przypisanie korzyści w byciu trzymanym w niewoli jest zarówno szowinizmem gatunkowym, jak i błędem atrybucji oraz antropomorfizacją. Zwierzęta ujmowane jako gatunki nie posiadają interesu w byciu trzymanymi, zabijanymi i hodowanymi przez ludzi.

Wracając do problemu postrzegania kategorii „Zwierzę” jako wielości, czyli pierwszeństwa gatunku - populacji przed jednostką, okaże się, że nakaz istnienia populacji zwierząt wynika przede wszystkim z naszej biopolityki. Foucault twierdzi, że suwerenna władza przekształca się w biowładzę wraz z narodzinami nauk policyjnych. Formuła takiej władzy sprowadza się do imperatywów: kazać żyć i pozwalać umierać (Foucault 2009). Czy w tym sensie pozostanie żywym aż do chwili otrzymania zgody na śmierć nie jest warunkiem konstytuowania się granicy podmiotowości między zakazem a pozwoleniem, którego przestrzeń wyznacza obszar gatunek - populacja - zwierzę? Oznaczałoby to, że zwierzę w zoo zajmuje przestrzeń nagiego życia, czyli wyznacza biopolityczną substancję, życie, które w swej nagości jest już nieodróżnialne od biologicznej masy. Idąc dalej za Giorgiem Agambenem, jest życiem, które można zabić, ale którego nie można złożyć w ofierze (2008). Populacja jako forma troski o gatunek wskutek rozwoju panoptykonu spojrzenia wiedzy-władzy stała się funkcją przetrwania. Zastępowalność, hodowla i nakazywanie życia są zatem czymś więcej niż ekologią i nauką, wyrażają paradygmat władzy spojrzenia, zamieniającej pytanie „dlaczego mamy prawo zabijać zwierzęta?” w pytanie „dlaczego nie mamy prawa pozwolić im umrzeć?”. Być może zwierzęta mają przeżyć własną śmierć po to, aby w przyszłości zdać świadectwo ze swojego cierpienia? Jednak czy życie upodlone i zubożone do stereotypii zniewolenia, stając się świadkiem całkowitym, będzie w stanie wysunąć oskarżenie przeciwko swoim oprawcom? Być może zburzenie dzisiejszej koncepcji świeckiej teodycei kazałoby postawić pytanie o to, czy lepsze byłoby istnienie od nieistnienia życia sprowadzonego do troski o populację? Podtrzymywanie istnienia gatunków zwierząt w niewoli nie jest wyborem interesu tych gatunków, lecz naszym kaprysem i zachcianką. Dlatego pytanie o kulturową konstrukcję zwierzęcia nie odsyła nas do czegoś na zewnątrz, lecz wpisuje się we współczesne debaty dotyczące dyskursywnej konstrukcji podmiotu. Patrząc na kulturowo wytworzone "artefakty” zwierząt trzymanych w niewoli, patrzymy z zadowoleniem na własną konstrukcję porządku ludzkie-nieludzkie. Spojrzenie w zoo należy umieścić w zachodniej tradycji interpelowania podmiotów mającej swój początek w nowożytnej nauce. 
Powracając do rozważań o zoo jako laboratoryzacji świata i ekspansji instrumentów wiedzo-władzy, udana hodowla, krzyżowanie i reprodukcja stały się źródłem sukcesu poznawczego i technologicznego nauk zootechnicznych, czyli wiedzy o racjonalnym chowie i użytkowaniu zwierząt. Tego rodzaju rozszerzanie się warunków wiwaryjnych pozwoliło na przekształcenie naturalnych środowisk życia istot żywych w nadzorowane parki i rezerwaty przyrody. Przykładem udanych praktyk restytucji, czyli przenoszenia zwierząt z zoo do przygotowanych na ich przyjęcie przestrzeni, nastąpiło w przypadku: żubra, jelenia milu, gnu brunatnego. Tego rodzaju praktyki pozwalają na ekstrapolację wniosków wyciągniętych $\mathrm{z}$ antropologii nauki i spojrzenie na zoo z perspektywy praktyki badawczej zacierającej granicę między zootechniką i jej przewidywaniami a technologią organizacji i reprodukcji życia zwierząt trzymanych w zoo. Tak więc sukces reprodukcji i restytucji staje się możliwy, ponieważ dokonuje się zmiany w populacjach zagrożonych gatunków, a następnie przeniesienia do przygotowanych środowisk o ograniczonej niestabilności biologicznej i niskim współczynniku występowania drapieżników i innych czynników doboru naturalnego. W ten sposób zoo staje się praktyką samouzasadniającą, tworzącą układ zamknięty, w którym dzięki izolacji tworzone są nowe natury zdolne przetrwać $\mathrm{i}$ istnieć poprzez zacieranie granicy między naturą a kulturą, wnętrzem a zewnętrzem, wolnością a zniewoleniem. Zatarciu ulega także granica między technologicznym wytwarzaniem natur i życia a wiedzą zdobywaną $\mathrm{w}$ trakcie tej praktyki. Wiedza to dostarcza wsparcia dla biopolityki i rozszerzania warunków hodowli na populacje żyjących gatunków.

\section{Podsumowanie}

Z dokonanych analiz wyłania się obraz kategorii „Zwierzę” jako konstrukcji kulturowej, w której to, co biologiczne, przeplata się tym, co społeczne. Skuteczność poznawczo-techniczna przyrody oraz zwierzęcia formowana jest poprzez dyscyplinowanie spojrzenia i przetwarzanie badanych obiektów. Poznanie naukowe jako unieruchamianie i domykanie układów odbywa się poprzez stosowanie przemocy wobec splotu rzeczywistości kultura-natura (Afeltowicz, Pietrowicz 2009: 35). W tej perspektywie należy się zastanowić się nad korzyściami rozbicia pojęcia „gatunku” i „zwierzęcia” na jego część biologiczną i kulturową. W końcu pojęcie natury i zwierzęcia we wszystkich analizach wykluczenia pojawiało się zawsze jako pierwotna matryca umieszczania jakiejś grupy istot poza granicą tego, co społeczne, polityczne i moralne. System wykluczeń natura - zwierzę - gatunek rasa - płeć przebierał to, co społeczne, w biologiczny determinizm, pozbawiając tak wykrojonych aktorów społecznych możliwości buntu i języka, przekształcając ich w biologiczne monady. Możliwość rozsadzenia monolitu natura - gatunek zwierzę poprzez przywoływanie i wydobywanie jego historycznego i językowego kontekstu pozwoliłoby na kontynuowanie etycznego projektu wyzwolenia zwierząt 
i jego społeczno-politycznego pozycjonowania. Naruszenie biologicznego autorytaryzmu omawianych kategorii otwiera przed nami pole możliwych interwencji politycznych na osi ludzkie - nieludzkie, podmiot - zwierzę.

Wracając do diagnozy współczesnej sytuacji „zwierzęcego”, możemy powiedzieć, że ciało zwierzęce, stanowi jedynie surowiec do realizacji naszych oczekiwań dotyczących tego, co chcemy ujrzeć w naturze sprowadzonej do przezroczystej kategorii nagiego życia. W ramach zachodniego dyskursu „zwierzę” staje się wytworem wiedzącego oka. Zoo jako laboratorium staje się zabezpieczeniem i kolekcją przedmiotów potwierdzających władzę naszego apetytu, ładu, porządku i dominacji. Staje się przestrzenią socjalizacji gatunkowej naszej koncepcji zachodniego androcentryzmu. W tym układzie nie ma miejsca na partnerstwo i odwiązanie od rzeczy aktorów i aktantów społecznych.

Stawką w projekcie emancypacyjnym zwierząt jest odzyskanie biologicznych zwierząt, które mogą stać się sojusznikiem w strategii zwracania i przepisywania teleologicznej tablicy taksonomii gatunku wystawianej przed klatką bądź wybiegiem. Chodzi o odzyskanie dla zwierząt ich natury, nawet jeśli każe nam to przyjąć tę kłopotliwą zewnętrzną pozycję człowiek/zwierzę. Musimy pamiętać, że dzisiejszy podział na ludzkie-nieludzkie nie jest niekwestionowalny i w świetle istniejących badań nad nauką potrafimy pokazać, w jaki sposób został uwikłany i spleciony $\mathrm{w}$ nasze cywilizacyjne partykularyzmy rozrywkowo-przemysłowe. Porzucenie zwierzęcia i pozostawianie go na pastwę spojrzenia nauki byłoby tym samym, co ucieczka dr. Frankensteina z laboratorium.

\section{Literatura}

Afeltowicz Ł., Pietrowicz K., 2009, Czy socjologowie sa w stanie budować maszyny spoteczne?, „Kultura i Społeczeństwo” nr 1.

Agamben G., 2008, Homo sacer: suwerenna władza i nagie życie, tłum. M. Salwa, Warszawa: Prószyński i S-ka.

Derrida J., 2008, Zwierzę, którym więc jestem (dalej idąc śladem), tłum. M. Koza, http:// www.academia.edu/3316323/Jacques_Derrida_Zwierze_ktorym_wiec_jestem_dalej_ idac_sladem_[dostęp: 13.10.2017].

Foucault M., 2009, Nadzorować i karać: narodziny więzienia, tłum. T. Komendant, Warszawa: Aletheia.

Foucault M., 2006, Stowa i rzeczy: archeologia nauk humanistycznych, tłum. T. Komendant, Gdańsk: słowo/obraz terytoria.

Gucwiński A., Strojny W., 1977, Znajomi z zoo, Warszawa: Państwowe Wydawnictwo Rolnicze i Leśne 41.

Haraway D., 2008, Wiedze usytuowane. Kwestia nauki w feminizmie i przywilej ograniczonej/częściowej perspektywy, tłum. A. Czarnacka, http://www.ekologiasztuka.pl/pdf/ f0062haraway1988.pdf [dostęp: 13.10.2017].

Horkheimer M., Adorno T., 2010, Dialektyka oświecenia: fragmenty filozoficzne, tłum. M. Łukasiewicz, Warszawa: Wydawnictwo Krytyki Politycznej. 
Jamieson, D., 2011, Przeciw ogrodom zoologicznym [w:] W obronie zwierząt, red. P. Singer, tłum. M. Betley, Warszawa: Czarna Owca.

Linneusz K., 1776, Systema naturae, s. 13, za: M. Foucault, 2006, Słowa i rzeczy: archeologia nauk humanistycznych, tłum. T. Komendant, Gdańsk: słowo/obraz terytoria, s. 149.

Macnaghten P., Urry J., 2005, Alternatywne przyrody, tłum. B. Baran, Warszawa: Scholar.

McCartney P., 2010, If slaughterhouses had glass walls, everyone would be vegetarian, https://www.youtube.com/watch?v=odgldsDVDis [dostęp: 13.10.2017].

McClintock A., 1995, Imperial leather: race, gender and sexuality in the colonial contess, New York-London: Routledge, http://selforganizedseminar.files.wordpress.com/2011/07/ mcclintock_imperial-leather.pdf [dostęp: 13.10.2017].

Paglia C., 1990, Sexual Personae: art and decadence from Nefertiti to Emily Dickinson, London: Yale University Press.

\begin{abstract}
Abstrakt
W statusie epistemologicznym ogrodów zoologicznych można zobaczyć realizację procesu wiedzy-władzy wspierającego coś więcej niż przestarzały kartezjański model nauki. Wycieczka do zoo to historyczna podróż do źródła paradygmatu poznania i pytania o sposób i znaczenie, jakie nadawane jest reprezentacji zwierząt. Zobaczyć zwierzęta w klatkach to jedna $\mathrm{z}$ pierwszych lekcji na temat tego, czym ma być wiedzące spojrzenie. Zdobycie doświadczenia poprzez obserwację prowadzi do przyjęcia oczywistości homogenizacji treści poznania ze środowiska naturalnego. Zwierzęta są przekształcane w obiekty poznania poprzez przekształcenie subiektywności ich doświadczenia w obiektywność laboratorium. Jako treści poznania są one poddawane ekspozycji w zamkniętym systemie klatka - wybieg - akwarium, które stanowią reprezentacje laboratoryzacji natury. Podobnie jak panoptykon tradycja istnienia ogrodów zoologicznych i ukształtowanego wokół nich dyskursu naucza, że wytwarzanie obiektywności = normatywności to proces konstruowania warunków ludzkiego spojrzenia jako relacji wiedzy-władzy.
\end{abstract}

\title{
Słowa kluczowe
}

zoo, posthumanizm, animal studies, laboratoryzacja, wiedza, władza, spojrzenie

\section{Summary}

\section{Zoo as a project of socialization}

The epistemological status of the zoo can be seen as a process of knowledge-power which supports something more than the Cartesian model of science. A visit to the zoo is a historical journey to the source of the cognition paradigm. Seeing animals in cages is the first lesson of what human perception should be like. It leads to adopting the attitude of gaining experience by homogenizing its contents from the natural environment. 
Animals were turned into the object of cognition by depriving them of subjectivity. As a content of knowledge, it is formulated in a closed system cage - pen - aquarium, which is a representation of laboratisation of nature. Just like panopticon the tradition of zoological gardens and the discourse shaped around them teaches that the production of objectivity $=$ normativity is a process of constructing the conditions of human perception in the form of a knowledge-power relation.

\section{Keywords}

zoo, posthumanism, animal studies, laboratisation, knowledge, power, gaze 